\title{
An overview of tourism risk perception
}

\author{
Fangnan Cui $^{1}$ - Yaolong Liu ${ }^{1}$ Yuanyuan Chang ${ }^{2}$.

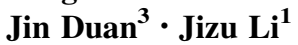

Received: 25 September 2015/ Accepted: 28 January 2016/Published online: 8 February 2016

(C) Springer Science+Business Media Dordrecht 2016

\begin{abstract}
In recent years, people pay more and more attention to travel safety and travel risks. Tourism risk perception is a quantitative assessment of tourism security. Destination risk perception of tourists directly affects tourists purchase intention. The asymmetry of the objective existence of tourist safety information and the subjective perception of tourists determines that tourists are extremely sensitive to travel risks. The inevitability of tourism risks requests that tourists have a certain level knowledge of destination environment. This study aimed to systematically review existing researches of tourism risk perception. The study shows: (1) Tourism risk perception includes three views, which were subjective feelings, objective evaluation and the cognition of exceeding the threshold portion of the negative consequences or negative impact that may occur during travel. (2) The subjective factors of tourism risk perception were the physical characteristics and psychological processes. The objective factors include physical risk, economic risk, equipment risk, social risk, psychological risk, time risk and opportunity loss. (3) The multi-dimensional model and the two-factor model were the two main types of risk perception assessment models. The survey (with interviews) and mathematical statistical analysis were the main research methods. Besides, this article highlights three points. (1) There is a certain critical value for travel risk perception of tourists; (2) cognitive ability is an important factor affecting the level of tourists objective risk perception; and (3) quantitative assessment of tourism risk perception level is helpful to the tourism decision making and destination management.
\end{abstract}

Keywords Tourism risk · Perception · Tourist - Influencing factors · Evaluation

Yaolong Liu

liuyaolong@tyut.edu.cn

1 College of Economics and Management, TaiYuan University of Technology, Taiyuan 030024, China

2 College of Physical Education, TaiYuan University of Technology, Taiyuan 030024, China

3 Institute of Poutics and Law, TaiYuan University of Technology, Taiyuan 030024, China 


\section{Introduction}

With the development of society and economy, the improvement of people's living standards and the increase in leisure time, the tourism industry grows rapidly. From the formation and development of world tourism, it has entered a period of steady development. Since the nineties, China's tourism industry has gone into the fast lane. In 2013, the number of domestic trips was 3.26 billion passengers and tourism revenue reached 2.6276 trillion yuan (People's Republic of China National Bureau of Statistics 2013). With the increase in people's travel times and extension of tourism space, the problem of travel safety is increasing and travel risks are growing. Tourism risk is that tourists in their travel behavior perceive negative results that may occur (Fischer et al. 1991; Chen et al. 2009). When tourists choose a tourist destination, they have to consider the security situation of their destination, but security cannot be quantified (Suddle 2009). So it is necessary to link security and risk (Lepp and Gibson 2003).

From the constructivist perspective to interpret, in contemporary society, it is not only that the risk is increasing (Beck 1999), people's attention and awareness of risk is greatly increasing (Liu 2009). Tourism risk perception is that tourists make a judgment of the uncertainty of tourism activities results and the process (Liu and Gao 2008). In the process of joining tourism activities, the objectivity of quantitative risk exists really, but the effect of subjective risk perception is more obvious (Cater 2006). Each visitor has a certain threshold that they can bear of the tourism risk perception. When the risk exceeds this threshold, visitors will try to reduce risk (Dirk 2003). Specific to the tourism activities, it is the impact of the tourism motivation and the choice of the way to travel and tourism (Teng 2009). In addition, the public's risk perception level is often used to analyze the psychological panic state.

Generally speaking, tourism risk perception theory involves psychology, sociology, culture, economics and many other disciplines. Risk information transmission, risk perception and risk response constitute the three elements of public risk communication. Risk perception is the psychological experience and understanding of the people's influence on the daily life and work. How to treat risk and whether it can accurately judge the hazard plays a key role in people's risk communication. Influencing factors analysis of risk perception and the amplification of negative factors are two important issues. To a certain extent, the collective explanation of risk information improves the level of public risk awareness, while it may also lead to disaster rumors (Quarantelli 1983; Prashant and Nicholas 2004; Carol 2015).

On the basis of researching literatures of the domestic and foreign scholars studying on tourism risk perception in system, from three aspects which are tourism risk perception's concept, factors and evaluation, this paper researches the progress in tourism risk perception evaluation and proposes three views of the concept of tourism risk perception. By analyzing the type of subjective and objective factors that affect tourism risk perception, the paper summarizes the basic idea, general methodology and mature conclusions of travel risk perception measurement and evaluation and proposes the foundation, critical and significance of travel risk perception evaluation.

\section{The concept of tourism risk perception}

Tourism is often regarded as a kind of consumer activity (Roselius 1997; Moutinho 1987; Zhang et al. 2004). Its risk is often that the product or service cannot meet the expectation of tourists or that is the collection of factors which are beyond the control during tourism consumption process (Oliver 1980; An and Fu 2005). With the development of "risk" 
concept (United Nation 1989; Jones and Boer 2003), tourism risk gradually is understood as the synthesis of two dimensions which are "the possibility that tourists subject to various unfortunate on a trip or a tourist destination" (Tsaur et al. 1997) and "tourists can not determine the consequences or negative results after making travel decisions" (Schiffman and Kanuk 2000; Chen et al. 2009).

Since the 1990s, tourist risk has been widely concerned by the scholars of cognitive psychology and consumer behavior (Sonmez and Graefe 1998a) and the concept of "tourism risk perception" came into being. Risk perception is generally used to describe a concept of people's attitude and intuitive judgment toward risk (Slovic 1987; Sitkin and Pablo 1992; Xie and Xu 1996). Bauer introduced the concept of risk to the consumer perception behavioral studies for the first time (Bauer 1960). The representation and definition of the concept of "Travel risk perception" are shown as follows (Table 1).

At present, the academic background of scholars engaged in tourism risk perception can be summarized as cognitive psychology, consumer behavior discipline and travel safety discipline. Correspondingly, the concept of "tourism risk perception" can also be divided into three views (Fig. 1), namely

1. Tourism risk perception is tourists' subjective feelings of the negative consequences or negative impact that may occur during travel;

2. Tourism risk perception is tourists' objective evaluation of the negative consequences or negative impact that may occur during travel;

3. Tourism risk perception is tourists' cognitive of exceeding the threshold portion of the negative consequences or negative impact that may occur during travel.

\section{Tourism risk perception factors}

\subsection{Subjective factors}

The two dimensions of tourism risk perception determine the factors affecting the tourism risk perception include subjective and objective factors (Brun 1992; Reisinger and

Table 1 The related concepts of tourism risk perception

\begin{tabular}{|c|c|c|}
\hline References & Concept & Definition \\
\hline $\begin{array}{l}\text { Sonmez and } \\
\text { Graefe (1998b) }\end{array}$ & $\begin{array}{l}\text { Travel risk } \\
\text { cognitive level }\end{array}$ & $\begin{array}{l}\text { Risk type and risk value which is been perceived by potential } \\
\text { tourists during international travel }\end{array}$ \\
\hline $\begin{array}{l}\text { Reichel et al. } \\
\text { (2007) }\end{array}$ & $\begin{array}{c}\text { Tourists risk } \\
\text { perception }\end{array}$ & $\begin{array}{l}\text { Consumers' negative impact perception on whether an event is } \\
\text { beyond the acceptable level of tourism behavior }\end{array}$ \\
\hline $\begin{array}{l}\text { Huang et al. } \\
\text { (2008) }\end{array}$ & $\begin{array}{r}\text { Tourists risk } \\
\text { perception }\end{array}$ & $\begin{array}{l}\text { The anxiety and psychological discomfort in the spiritual or } \\
\text { supernatural beliefs of buying and consuming certain destination } \\
\text { travel services for the tourists }\end{array}$ \\
\hline $\begin{array}{l}\text { Liu and Gao } \\
\text { (2008) }\end{array}$ & $\begin{array}{l}\text { Travel risk } \\
\text { perception }\end{array}$ & $\begin{array}{l}\text { The subjective judgment of tourists on the uncertainty of the } \\
\text { process and results of tourism activities }\end{array}$ \\
\hline $\begin{array}{l}\text { Wong and Yeh } \\
\text { (2009) }\end{array}$ & $\begin{array}{r}\text { Tourists risk } \\
\text { perception }\end{array}$ & $\begin{array}{l}\text { Tourists perceive the possibility of negative consequences and the } \\
\text { extent of uncertainty of purchasing the product on destinations }\end{array}$ \\
\hline Zhang (2009) & $\begin{array}{c}\text { Tourism risk } \\
\text { perception }\end{array}$ & $\begin{array}{l}\text { A subjective evaluation of the deviation between the psychological } \\
\text { expectation and the objective effect of the tourist behavior }\end{array}$ \\
\hline $\begin{array}{l}\text { Chen and Zhang } \\
\text { (2012a) }\end{array}$ & $\begin{array}{c}\text { Tourism risk } \\
\text { perception }\end{array}$ & $\begin{array}{l}\text { The intuitive judgments and subjective feelings of various potential } \\
\text { risks which exist in different tourism projects for tourists }\end{array}$ \\
\hline
\end{tabular}




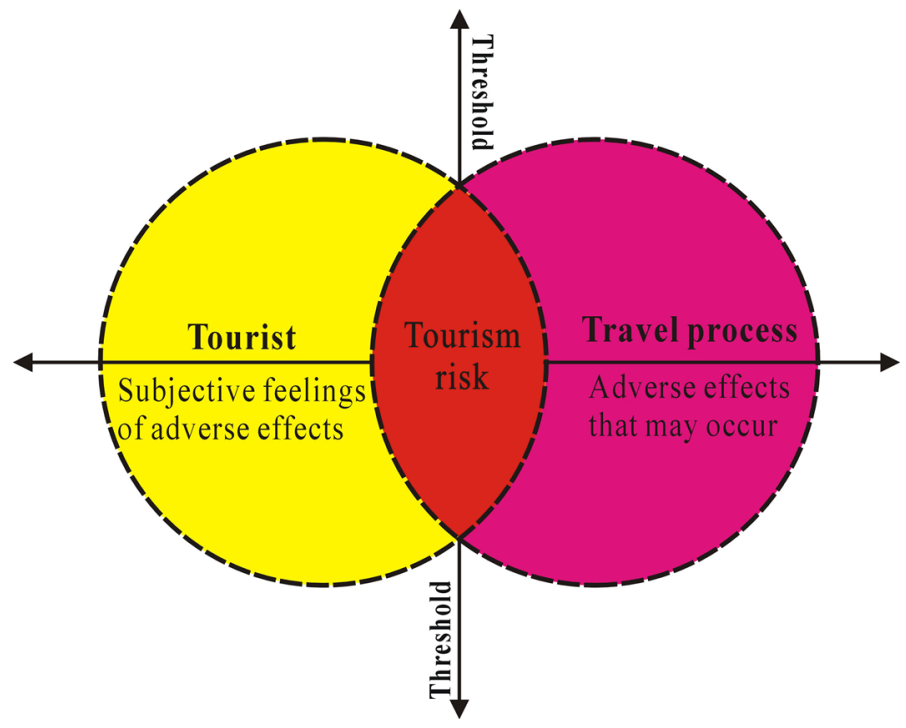

Fig. 1 Three views of tourism risk perception concept

Mavondo 2006; Kozak et al. 2007). As mentioned above, cognitive psychology school concerns tourists' subjective feelings of the negative consequences or negative impact that may occur during travel. The tourism risk perception is significantly influenced by the physical characteristics and psychological processes (such as attention, perception, effect of representation, memory, thinking and language skills) of tourists. Table 2 shows the researching results of the subjective factors of tourism risk perception from scholars in recent years.

Currently, the subjective factors affecting tourism risk perception can be divided into two categories, namely demographic variables and individual cognitive abilities. The former includes age, gender, educational experience, academic background, social status, geography, education level, income and social experience. The latter focuses on temperament, personality, emotions, outlook, values, cognitive and meta-cognitive and so on. Subjective factors influencing tourism risk perception mainly are as follows (Ahmad et al. 2015):

1. Women's sensibility for travel risk is slightly higher than that of men;

2. The similarity of culture and psychology and spatial contiguity of geographical position determines the feeling of tourists for the loss;

3. When people have the higher level of education, the more frequent contact with media people and the higher the class status, the level of their risk perception is stronger;

4. When people are more confidence with information sources and agencies, their risk perception is stronger;

5. Urban residents have a stronger risk perception than rural residents;

6. People's concerns, anxiety and other emotions for travel risk can affect individual's awareness of risk perceptions, whereas the understanding of the individual's tourism risks will also affect their emotional intensity. 
Table 2 Subjective factors of tourism risk perception

\begin{tabular}{|c|c|c|}
\hline References & Factors & Explanation \\
\hline Wu et al. (2001) & Individual differences & $\begin{array}{l}\text { Personal economic status, gender and place } \\
\text { of residence, etc. }\end{array}$ \\
\hline An and Fu (2005) & Personality differences & $\begin{array}{l}\text { Demographic variables (including age, } \\
\text { gender and education) geography, culture } \\
\text { (professional or amateur) and } \\
\text { psychological proximity, etc. }\end{array}$ \\
\hline $\begin{array}{l}\text { Boksbergera et al. } \\
\text { (2007) }\end{array}$ & Psychological risk & $\begin{array}{l}\text { Refer to the possibility of passengers feeling } \\
\text { embarrassed or self-esteem damaged } \\
\text { during the flight }\end{array}$ \\
\hline Reichel et al. (2007) & Individual differences & $\begin{array}{l}\text { Include gender, past experience and } \\
\text { willingness to travel with their peers }\end{array}$ \\
\hline \multirow[t]{4}{*}{ Chen et al. (2009) } & Pursuit of foreign culture & $\begin{array}{l}\text { Include liking to live and tour with local } \\
\text { people's habits, coordinating with local } \\
\text { residents, the pursuit of novelty, making } \\
\text { friends with local residents, contacting } \\
\text { with local residents and selecting not } \\
\text { preplanned itinerary }\end{array}$ \\
\hline & Pursuit of exotic circle & $\begin{array}{l}\text { Include liking a long-term stay in-depth } \\
\text { exchanges, using similar tourist facilities, } \\
\text { similar national culture, preferring the } \\
\text { familiar dining and restaurants, using } \\
\text { similar transportation systems and } \\
\text { accepting the same kind of intimate } \\
\text { familiar feeling }\end{array}$ \\
\hline & Pursuit of travel services & $\begin{array}{l}\text { Include liking travel agency throughout the } \\
\text { management, traveling with tour guides } \\
\text { and travel agency booking operation }\end{array}$ \\
\hline & Pursuit of popularity & $\begin{array}{l}\text { Include the willingness to decide things } \\
\text { according to their own ideas, liking the } \\
\text { well-known popular tourist destination, the } \\
\text { tourism industry in developed countries } \\
\text { and international chain hotels }\end{array}$ \\
\hline Li (2010) & Psychological risk & $\begin{array}{l}\text { Tourist will have unnecessary worry, tension } \\
\text { and psychological discomfort }\end{array}$ \\
\hline \multirow[t]{2}{*}{ Wang (2010) } & Individual cognitive abilities & $\begin{array}{l}\text { The education level is higher and then the } \\
\text { risk of cognitive ability is stronger }\end{array}$ \\
\hline & Social class status & $\begin{array}{l}\text { The class status is higher and then the risk of } \\
\text { cognitive ability is stronger }\end{array}$ \\
\hline \multirow[t]{4}{*}{$\begin{array}{l}\text { Chen and Zhang } \\
(2012 b)\end{array}$} & Personality differences & $\begin{array}{l}\text { Refer to the difference of personality, such } \\
\text { as external control type and internal type }\end{array}$ \\
\hline & Knowledge and experience & $\begin{array}{l}\text { Tourists often participate in travel activities } \\
\text { and have accumulated a wealth of } \\
\text { theoretical knowledge and practical } \\
\text { experience }\end{array}$ \\
\hline & $\begin{array}{l}\text { Risk perception and cognitive } \\
\text { benefits }\end{array}$ & $\begin{array}{l}\text { Perceived risk is greater cognitive benefits, } \\
\text { or less than the cognitive benefits }\end{array}$ \\
\hline & Information Trust & $\begin{array}{l}\text { The trust level of individual for information } \\
\text { sources and agencies }\end{array}$ \\
\hline Zhang (2012b) & Psychosocial risk & $\begin{array}{l}\text { Tourism products are not being recognized } \\
\text { while others, which leads to the risk of } \\
\text { self-image or self-concept damage }\end{array}$ \\
\hline
\end{tabular}


Table 2 continued

\begin{tabular}{lll}
\hline References & Factors & Explanation \\
\hline Zhang et al. (2013) & Gender & $\begin{array}{c}\text { Women are more concerned about the } \\
\text { adverse consequences of climate change } \\
\text { People grow older and the concern of } \\
\text { climate change is also growing }\end{array}$ \\
& $\begin{array}{l}\text { Level of education affects the judgments of } \\
\text { risk perception }\end{array}$ \\
& $\begin{array}{l}\text { Mainly refer to the various climatic } \\
\text { phenomena which have been first-hand } \\
\text { experience }\end{array}$ \\
& $\begin{array}{l}\text { Emotion and risk perception are a process of } \\
\text { interaction } \\
\text { Emotion }\end{array}$ \\
Dorldview & $\begin{array}{l}\text { Different world views lead to different } \\
\text { climate change risk perceptions }\end{array}$ \\
\end{tabular}

\subsection{Objective factors}

The objective factors affecting tourism risk perception mainly refer to negative consequences or negative impact that may occur during travel. They can be summarized as multiple dimensions of tourism risk. Table 3 shows the results of scholars' studies about objective factors of tourism risk perception in recent years. Tourists risk perception is often five to seven dimensions, namely

1. five-dimension risk: psychological risk, financial risk, performance risk, health risk and social risk;

2. six-dimension risk: performance risk, physical risk, financial risk, psychological risk, social risk and time risk;

3. seven-dimension risk: physical risk, economic risk, equipment risk, social risk, psychological risk, time risk and opportunity loss.

It should be noted that the multi-dimensional tourism risk factors often include "psychological risk." The school of consumer behavior recognizes the psychological factor as the cognitive of tourists for their behavior after they make the wrong purchase decision. In recent years, the gradual development of tourism safety leads to the study on tourism safety cognition (Zheng 2009). Tourism security school considers that the objective factors affecting tourism safety perception include the social and natural environment in tourist destinations and the security situation of "food, housing, transportation, travel, shopping, entertainment" in the process of travel (Wu et al. 2001; Yvette and Felix 2005; Atila and Fisun 2007; Zhu 2008).

"Through summarizing and analyzing the relevant literature, the dominant risk factors influencing the tourism are proposed for different types of tourism resources and different tourism groups (Table 4). The first three factors influencing the tourism risk when tourists visit different types of destination were listed in the left part of Table 4. The risk degree is characterized by star numbers. Specifically, physical risk is most important for natural tourism resources or scenic areas (such as land scenery, waters scenery, biological landscape, astronomer and climatic scenery), followed by equipment risk and performance risk. For cultural relics such as sites, sites, buildings, etc., the equipment risk was the most 
Table 3 Objective factors of tourism risk perception

\begin{tabular}{|c|c|c|}
\hline References & Appellation & Connotation \\
\hline \multirow[t]{2}{*}{$\begin{array}{l}\text { Tsaur et al. } \\
\text { (1997) }\end{array}$} & Personal risk & $\begin{array}{l}\text { Due to the possibility of security, weather, health and so on causing } \\
\text { the damage of personal body health }\end{array}$ \\
\hline & Equipment risk & $\begin{array}{l}\text { Refer to the danger caused by equipment failure, such as traffic } \\
\text { accidents }\end{array}$ \\
\hline \multirow[t]{2}{*}{$\begin{array}{l}\text { Wu et al. } \\
\text { (2001) }\end{array}$} & Natural factors & $\begin{array}{l}\text { Custom difference, facilities security, climate conditions, tourists } \\
\text { crowded, lost, environmental pollution, cultural differences, local } \\
\text { attitudes, natural disasters, rebates and strong sell }\end{array}$ \\
\hline & Artificial factors & $\begin{array}{l}\text { Epidemic diseases, accidents, law and order situation, sexual } \\
\text { harassment, sexually transmitted diseases, quality of service, } \\
\text { health factors, personal uncivilized and local economic } \\
\text { conditions }\end{array}$ \\
\hline \multirow{5}{*}{$\begin{array}{r}\text { Dolnicar } \\
(2005)\end{array}$} & Political risk & Include terrorist attacks and the unstable political environment \\
\hline & Environmental risk & Include natural disasters and landslides \\
\hline & Health risk & $\begin{array}{l}\text { Include difficult access to health care and the existence of life- } \\
\text { threatening diseases }\end{array}$ \\
\hline & Plan risk & Include unreliable airlines and inexperienced operations \\
\hline & Property risk & Include theft and luggage lost \\
\hline \multirow{5}{*}{$\begin{array}{l}\text { Boksberger } \\
\text { et al. } \\
(2007)\end{array}$} & Financial risk & $\begin{array}{l}\text { Refer that the purchase of service is not worth and money does not } \\
\text { achieve the best value }\end{array}$ \\
\hline & Functional risk & $\begin{array}{l}\text { Refer to the problems occurring during the service, poor quality of } \\
\text { service and passengers not getting the best service }\end{array}$ \\
\hline & Personal risk & $\begin{array}{l}\text { Refer to the possibility of passenger's hurting during the aircraft } \\
\text { encountering an accident }\end{array}$ \\
\hline & Social risk & $\begin{array}{l}\text { Due to the selected airline happening the reputation damaged } \\
\text { event, the possibility that others will change the impression of } \\
\text { passengers }\end{array}$ \\
\hline & Time risk & $\begin{array}{l}\text { Checking in, schedule delays and other conditions cause the } \\
\text { possibility of wasting time }\end{array}$ \\
\hline \multirow[t]{2}{*}{$\begin{array}{r}\text { Moreira } \\
(2007)\end{array}$} & Invisible risk & $\begin{array}{l}\text { Risks will happen over time, though the situation now is still } \\
\text { neutral or positive, such as air quality }\end{array}$ \\
\hline & Catastrophe risk & $\begin{array}{l}\text { Refer to the possibility of suddenly having a negative impact on the } \\
\text { current reality by a serious accident or a natural disaster, such as } \\
\text { earthquakes, typhoons }\end{array}$ \\
\hline \multirow[t]{8}{*}{$\begin{array}{l}\text { Liu and Gao } \\
(2008)\end{array}$} & Property risk & $\begin{array}{l}\text { Tourists feel the risk when they purchase the wrong tourism } \\
\text { product }\end{array}$ \\
\hline & Performance risk & $\begin{array}{l}\text { Tourists feel the risk when the quality of tourism products do not } \\
\text { meet the expectations of tourists }\end{array}$ \\
\hline & Health risk & $\begin{array}{l}\text { Tourists feel the risk when the body would be injured due to illness, } \\
\text { accident, security and other factors during the trip }\end{array}$ \\
\hline & Social risks & $\begin{array}{l}\text { Tourists feel the risk when the choice of tourism products are not } \\
\text { recognized by others }\end{array}$ \\
\hline & Psychological risk & $\begin{array}{l}\text { Refer to the purchase of certain tourism products leading to a loss } \\
\text { of self-image }\end{array}$ \\
\hline & Medical risks & $\begin{array}{l}\text { Refer to the damages for tourists by whether healthcare services in } \\
\text { a timely manner or not }\end{array}$ \\
\hline & Security risk & $\begin{array}{l}\text { Refer to the threat of law and order conditions in tourist destination } \\
\text { for tourists }\end{array}$ \\
\hline & Facilities risk & $\begin{array}{l}\text { The risk is caused by the safety of all kinds of facilities and } \\
\text { equipment during the journey }\end{array}$ \\
\hline
\end{tabular}


Table 3 continued

\begin{tabular}{|c|c|c|}
\hline References & Appellation & Connotation \\
\hline \multirow[t]{3}{*}{$\begin{array}{l}\text { Chen et al. } \\
\text { (2009) }\end{array}$} & $\begin{array}{l}\text { Terrorist attacks and } \\
\text { war risk }\end{array}$ & $\begin{array}{l}\text { Include the possibility of a terrorist incident, the target of terrorist } \\
\text { organizations, terrorist incidents recurring, war and national riots }\end{array}$ \\
\hline & Public health risk & $\begin{array}{l}\text { Include the risk of staining of the disease and the possibilities of } \\
\text { SARS outbreak, bird flu infection and epidemic disease large } \\
\text { outbreak }\end{array}$ \\
\hline & $\begin{array}{l}\text { Natural disasters and } \\
\text { financial risk }\end{array}$ & $\begin{array}{l}\text { Include the possibility of earthquakes, tsunamis, flash floods, the } \\
\text { financial crisis and significant changes in the exchange rate }\end{array}$ \\
\hline \multirow[t]{8}{*}{ Li (2010) } & Personal risk & Landslide and aftershocks cause injury during traveling \\
\hline & Health risk & $\begin{array}{l}\text { Bacteria and radioactive contamination caused by the earthquake, } \\
\text { toxic spills, plague and various epidemic diseases threaten health }\end{array}$ \\
\hline & Value risk & $\begin{array}{l}\text { Whether the travel is worthwhile, good value and has an impact on } \\
\text { the economic situation }\end{array}$ \\
\hline & Moral hazard & $\begin{array}{l}\text { The tourists is considered disrespect to the locals and the dead } \\
\text { when they visit the scenic }\end{array}$ \\
\hline & Social risk & $\begin{array}{l}\text { Visiting the scenic would be detrimental to the tourists' self-image } \\
\text { and change the think of friends and family to them }\end{array}$ \\
\hline & Time risk & Because of the earthquake, it will spend more time traveling \\
\hline & Convenient risk & $\begin{array}{l}\text { The earthquake causing damage to various public facilities affects } \\
\text { the life in the area }\end{array}$ \\
\hline & Crime risk & $\begin{array}{l}\text { After the earthquake, crime breeds confusion and personal safety is } \\
\text { threatened by becoming the target of criminals }\end{array}$ \\
\hline \multirow{6}{*}{$\begin{array}{l}\text { Fuchs and } \\
\text { Reichel } \\
\text { (2011) }\end{array}$} & Artificial risk & Include crime, terrorist attacks and political unrest \\
\hline & Financial risk & $\begin{array}{l}\text { Include the affection of personal economic consequences due to the } \\
\text { unexpected consumption and travel }\end{array}$ \\
\hline & Service quality risk & Include strikes, unsatisfactory facilities and unfriendly shopkeepers \\
\hline & Psychosocial risk & Include trip impact on self-image and others' reactions \\
\hline & $\begin{array}{l}\text { The risk of natural } \\
\text { disasters and } \\
\text { accidents }\end{array}$ & $\begin{array}{l}\text { Refer to the possibility of the occurrence of natural disasters and } \\
\text { accidents }\end{array}$ \\
\hline & $\begin{array}{l}\text { Food safety issues } \\
\text { and weather }\end{array}$ & $\begin{array}{l}\text { Refer to the problem of food security and the possibility of adverse } \\
\text { weather }\end{array}$ \\
\hline \multirow[t]{7}{*}{ Hu (2011) } & Health risk & $\begin{array}{l}\text { Due to equipment, natural, infectious diseases, merchandise and } \\
\text { other reasons, it leads to the risk of bodily harm }\end{array}$ \\
\hline & Economic risk & $\begin{array}{l}\text { The risk of the loss of money is caused by the price of tourism } \\
\text { products far beyond their cost or the price of product reducing }\end{array}$ \\
\hline & Performance risk & $\begin{array}{l}\text { The risk is caused by the poor quality of tourism product and } \\
\text { service or the quality of tourism product and service not meeting } \\
\text { consumer expectations }\end{array}$ \\
\hline & Social risk & $\begin{array}{l}\text { Tourists feel social insecurity, political turmoil, terrorism, crime, } \\
\text { etc. when they enjoy tourism products }\end{array}$ \\
\hline & Psychological risk & $\begin{array}{l}\text { Tourists feel unsafe when they encounter foreign language barriers } \\
\text { and cultural impact during traveling }\end{array}$ \\
\hline & Time risk & $\begin{array}{l}\text { The possibility of excessively consuming time when tourists } \\
\text { consume tourism products }\end{array}$ \\
\hline & Opportunity loss & $\begin{array}{l}\text { The risk that tourists will miss the alternative when they buy one } \\
\text { tourism product }\end{array}$ \\
\hline
\end{tabular}


Table 3 continued

\begin{tabular}{|c|c|c|}
\hline References & Appellation & Connotation \\
\hline \multirow{2}{*}{$\begin{array}{l}\text { Chen and } \\
\text { Zhang } \\
(2012 a)\end{array}$} & Risk characteristics & $\begin{array}{l}\text { Refer to a class of common risk which has the same degree of fear } \\
\text { and unknown }\end{array}$ \\
\hline & $\begin{array}{l}\text { Media } \\
\text { communication }\end{array}$ & The media may affect the visitors' cognitive of sports tourism risk \\
\hline \multirow[t]{5}{*}{$\begin{array}{l}\text { Zhang } \\
\text { (2012a) }\end{array}$} & Financial risk & $\begin{array}{l}\text { Tourists feel the risk when the purchase of travel products or } \\
\text { services costs more than expected price }\end{array}$ \\
\hline & Performance risk & $\begin{array}{l}\text { Tourists feel the risk when the quality of tourism products cannot } \\
\text { meet their expectations }\end{array}$ \\
\hline & Health risk & $\begin{array}{l}\text { Refer to the risk of causing body injury due to changes in the } \\
\text { environment, accidents, security and other factors }\end{array}$ \\
\hline & Convenient risk & $\begin{array}{l}\text { The risk is caused by the uncertainty of time and energy that } \\
\text { tourists spend on purchasing travel products }\end{array}$ \\
\hline & Facilitate risk & $\begin{array}{l}\text { The risk is caused by the safety of all kinds of facilities and } \\
\text { equipment during the journey }\end{array}$ \\
\hline
\end{tabular}

important. For tourism commodity and cultural tourism activities, financial risk may be the most concern of tourists.

Correspondingly, the right part of Table 4 lists the risk factors which tourists of different ages pay more attention to during the traveling. For example, teenagers and old people may more care about physical risk and equipment risk, while youth focuses on financial risk and middle-aged people mind time risk."

\section{Evaluation of tourism risk perception}

Tourism risk perception assessment is the process of qualitative analysis and measurement to the subjective and objective factors affecting tourists risk perception (Fuchs and Reichel 2004, 2006; Eitzigera and Wiedemannb 2007), which includes:

1. Analysis on tourism risk perception factors and dimensions design;

2. Tourism risk perception evaluation model construction and weight determination;

3. Measurement and classification of tourism risk perception level;

4. Impact of statistical factor for tourism risk perception.

For the tourism system, tourism risk assessment has two main methods (An and Fu 2005; Wang 2010), namely risk expected evaluation and tourists risk perception. The former is the process of estimating the tourism risk on the basis of reasonable expectation without considering tourist value. The latter focuses on the assessment of tourist subjective risk perception, reflecting the personality differences and property values of tourists.

It should be noted that "tourism risk perception assessment" is often confused with "travel risk assessment." The former can be understood as the research of "tourism risk" concept's first and third view. The latter is focused on the second view of the concept of "tourism risk." It should be said that scholars in the field of natural sciences (such as environmental science, geography, biology, disaster science and safety study) prefer researching "travel risk assessment." Scholars in the field of social sciences (such as psychology, economics, behavioral science, sociology and management) are deeper concern about "tourism risk perception assessment." 
Table 4 The dominant factors influencing tourism risk perception under different situations

\begin{tabular}{|c|c|c|c|c|c|}
\hline Tourism resources type & Risk factors & $\begin{array}{l}\text { Risk } \\
\text { degree }\end{array}$ & Tourists & Risk factors & $\begin{array}{l}\text { Attention } \\
\text { degree }\end{array}$ \\
\hline \multirow{3}{*}{$\begin{array}{l}\text { Land scenery, waters scenery, biological } \\
\text { landscape, astronomer and climatic } \\
\text { scenery }\end{array}$} & Physical risk & $\star \star \star$ & Teenagers & Physical risk & $\star \star \star$ \\
\hline & $\begin{array}{l}\text { Equipment } \\
\text { risk }\end{array}$ & $\star \star$ & & $\begin{array}{l}\text { Equipment } \\
\text { risk }\end{array}$ & $\star \star$ \\
\hline & $\begin{array}{l}\text { Performance } \\
\text { risk }\end{array}$ & $\star$ & & $\begin{array}{l}\text { Performance } \\
\text { risk }\end{array}$ & $\star$ \\
\hline \multirow[t]{3}{*}{$\begin{array}{l}\text { Sites and ruins, construction and } \\
\text { facilities }\end{array}$} & $\begin{array}{l}\text { Equipment } \\
\text { risk }\end{array}$ & $\star \star \star$ & Youth & $\begin{array}{l}\text { Financial } \\
\text { risk }\end{array}$ & $\star \star \star$ \\
\hline & Physical risk & $\star \star$ & & Time risk & $\star \star$ \\
\hline & $\begin{array}{l}\text { Performance } \\
\text { risk }\end{array}$ & $\star$ & & Physical risk & $\star$ \\
\hline \multirow[t]{3}{*}{ Tourism commodity } & $\begin{array}{l}\text { Financial } \\
\text { risk }\end{array}$ & $\star \star \star$ & $\begin{array}{l}\text { Middle- } \\
\text { aged }\end{array}$ & Time risk & $\star \star \star$ \\
\hline & $\begin{array}{l}\text { Performance } \\
\text { risk }\end{array}$ & $\star \star$ & people & Physical risk & $\star$ \\
\hline & $\begin{array}{l}\text { Equipment } \\
\text { risk }\end{array}$ & $\star$ & & $\begin{array}{l}\text { Financial } \\
\text { risk }\end{array}$ & $\star$ \\
\hline \multirow[t]{3}{*}{ Cultural tourism activities } & $\begin{array}{l}\text { Financial } \\
\text { risk }\end{array}$ & $\star \star \star$ & $\begin{array}{l}\text { Old } \\
\text { people }\end{array}$ & Physical risk & $\star \star \star$ \\
\hline & Physical risk & $\star \star$ & & $\begin{array}{l}\text { Equipment } \\
\text { risk }\end{array}$ & $\star \star$ \\
\hline & $\begin{array}{l}\text { Equipment } \\
\text { risk }\end{array}$ & $\star$ & & $\begin{array}{l}\text { Financial } \\
\text { risk }\end{array}$ & $\star$ \\
\hline
\end{tabular}

\subsection{Evaluation model}

In accordance with the content of the evaluation, tourism risk perception evaluation model is divided into two categories: conceptual model and factor model. The former is from the concept of tourism risk perception, stressing the subjective feeling of tourists on travel services' "uncertainty" and "dangerousness of consequence." It is also known as twofactor model (Cunningham 1967; Peter and Ryan 1976; Whyte and Burton 1982; Ammann 2006; Schneider et al. 2006). Researchers often use simple weighted model to evaluate the tourism risk perception level of tour groups comprehensively (Roehl and Fesenmaier 1992; Cao and Wang 2001; Boksbergera et al. 2007; Liu and Gao 2008; Zhang 2012a). The model can be expressed as:

$$
T R P=\sum_{i=1}^{n}\left(\alpha_{i} \times P L_{r i} \times I L_{r i}\right)
$$

Among them, TRP is tourism risk perception; $\alpha_{i}$ is the weight of each dimension of the tourism risk perception; $r_{i}$ is the risk of each dimension $(i=1,2,3, \ldots, n) ; P L_{r i}$ is the possibility of each dimension risk; and $I L_{r i}$ is the harm of each dimension risk.

This kind of model is based on the concept of risk. In different situations, the risks are weighted and quantified to evaluate tourism risk perception. The advantage of the model is that it is specific and the factors determination and the data acquisition are precise. The latter considers the subjective and objective factors of tourism risk perception, which is 
called "multi-dimensional model." This model has no fixed form, and the relevant questionnaire is designed according to different tourism scenarios. And then, the "Likert scale" is used to quantify the factors. Finally, the results are processed by statistical method, so as to complete the evaluation of tourism risk perception (Wu et al. 2001; Myron et al. 2004; Chen et al. 2009; Fuchs and Reichel 2011; Li et al. 2011; Fuchs 2013; Lin and Hsu 2013; Chiao and Vikneswaran 2014).

The advantage of this model is that it can reflect various subjective and objective factors which affect the tourism risk perception, and it is flexible and changeable, and it can deal with all kinds of different risk scenarios. Table 5 shows the evaluation models and methods of the tourism risk perception which is used by scholars in recent years. Currently, the tourism risk perception evaluation model used by scholars can be understood as the corrections or improvements of the two types of models mentioned above.

\subsection{Evaluation method}

Tourism risk perception assessment includes data acquisition method and data processing method. Scholars use questionnaires, supplemented by interviews and statistics when they

Table 5 Evaluation models and methods of tourism risk perception

\begin{tabular}{|c|c|c|c|}
\hline \multirow[t]{2}{*}{ References } & \multirow{2}{*}{$\begin{array}{l}\text { Evaluation } \\
\text { model }\end{array}$} & \multicolumn{2}{|l|}{ Evaluation methods } \\
\hline & & Data sources & Data Processing \\
\hline $\begin{array}{l}\text { Wu et al. } \\
\text { (2001) }\end{array}$ & $\begin{array}{l}\text { Multi- } \\
\text { dimensional } \\
\text { model }\end{array}$ & Questionnaire & $\begin{array}{l}\text { Simple summary analysis, factor analysis and } \\
\text { geographic information systems }\end{array}$ \\
\hline $\begin{array}{l}\text { Myron } \\
\text { et al. } \\
(2004)\end{array}$ & $\begin{array}{l}\text { Multi- } \\
\text { dimensional } \\
\text { model }\end{array}$ & $\begin{array}{l}\text { Telephone access, } \\
\text { Statistical yearbook }\end{array}$ & $\begin{array}{l}\text { Principal component analysis and regression } \\
\text { analysis }\end{array}$ \\
\hline $\begin{array}{l}\text { Liu and } \\
\text { Gao } \\
(2008)\end{array}$ & $\begin{array}{l}\text { Two-factor } \\
\text { model }\end{array}$ & $\begin{array}{l}\text { Questionnaire(Snowball } \\
\text { method) }\end{array}$ & $\begin{array}{l}\text { Correlation analysis, factor analysis, variance } \\
\text { analysis and cluster analysis }\end{array}$ \\
\hline $\begin{array}{l}\text { Chen et al. } \\
\text { (2009) }\end{array}$ & $\begin{array}{l}\text { Multi- } \\
\text { dimensional } \\
\text { model }\end{array}$ & Questionnaire & Factor analysis and multiple regression analysis \\
\hline $\begin{array}{l}\text { Zhang } \\
\text { (2009) }\end{array}$ & $\begin{array}{l}\text { Two-factor } \\
\text { model }\end{array}$ & $\begin{array}{l}\text { Questionnaire, } \\
\text { Statistical data }\end{array}$ & Correlation analysis and variance analysis \\
\hline $\begin{array}{l}\text { Fuchs and } \\
\text { Reichel } \\
(2011)\end{array}$ & $\begin{array}{l}\text { Multi- } \\
\text { dimensional } \\
\text { model }\end{array}$ & Questionnaire & $\begin{array}{l}\text { Cross-analysis, discriminant analysis, variance } \\
\text { analysis, and afterward Scheffe test and Chi- } \\
\text { square analysis }\end{array}$ \\
\hline $\begin{array}{l}\text { Li et al. } \\
\text { (2011) }\end{array}$ & $\begin{array}{l}\text { Multi- } \\
\text { dimensional } \\
\text { model }\end{array}$ & Questionnaire & $\begin{array}{l}\text { ANOVA analysis and structural equation } \\
\text { modeling }\end{array}$ \\
\hline $\begin{array}{l}\text { Zhang } \\
\qquad(2012 a)\end{array}$ & $\begin{array}{l}\text { Two-factor } \\
\text { model }\end{array}$ & Questionnaire & Multiple regression analysis \\
\hline $\begin{array}{l}\text { Chen and } \\
\text { Zhang } \\
(2012 b)\end{array}$ & $\begin{array}{l}\text { Multi- } \\
\text { dimensional } \\
\text { model }\end{array}$ & Interview, Questionnaire & $\begin{array}{l}\text { Significant analysis, one-way ANOVA and } \\
\text { factor analysis }\end{array}$ \\
\hline $\begin{array}{l}\text { Fuchs } \\
\qquad(2013)\end{array}$ & $\begin{array}{l}\text { Multi- } \\
\text { dimensional } \\
\text { model }\end{array}$ & Depth interview & $\begin{array}{l}\text { Factor analysis, discriminant analysis and } \\
\text { coding instructions }\end{array}$ \\
\hline
\end{tabular}


get quantitative data on the subjective and objective factors of tourism risk perception (Table 5). The difference is the design of questionnaire and sampling methods. They often use "Likert scale" in the evaluation of tourism risk.

Currently, the statistical method is widely used in the data processing of tourism risk perception assessment, such as basic descriptive statistics, correlation analysis, regression analysis, cluster analysis, variance analysis and factor analysis. The statistical analysis software includes SPSS, SAS, Visual FoxPro, Excel and Orange. It should be noted that some scholars have tried to introduce GIS software in this issue to reflect the spatial distribution of tourism risk perception in the form of thematic maps.

\subsection{Evaluation results}

The result of tourism risk perception assessment is divided into quantitative indicators and qualitative conclusions. The former includes frequency, mean (risk perception evaluation value), standard deviation, Cronbach's alpha, correlation coefficients, adjoint probability, regression coefficients, factor load, the characteristic roots and explained variance. The latter's general conclusions can be summarized as follows:

1. The greatest impact on tourists' sense of security is social security;

2. Travel distance has a positive correlation with travel fear and strangeness;

3. Travel experiences have a significant impact on the risk perception (especially social risk);

4. Tourists concern the entity risk more than the invisible risk;

5. There is a negative correlation between risk perception and the preference of travel behavior;

6. For the first time, visitors often pay attention to human risk, psychosocial risk, food safety and weather risk. Then, visitors are more concerned about the risk of finances, quality of service, natural disasters and accidents;

7. There is a certain correlation between the level of tourism risk perception, destination satisfaction and the impact of natural disasters;

8. There are significant differences of cognitive between travel risk's internal dimensions and its attributes;

9. The risk cognitive level of the people at the mature age is higher than that of the age of puberty and sturdy;

10. When tourists seek stimulate, the impact on tourism risk perception is greater; high sensation seekers have a stronger perception on the external risks.

\section{Conclusion and discussion}

The research of travel risk perception has been more than half a century. The science of consumer behavior, cognitive psychology and tourism safety explore the characterization of tourism risk and the evaluation of risk perception from a different perspective. Sum up as follows:

1. There were three views of tourism risk perception, which were subjective feelings of the negative consequences or negative impact that may occur during travel, objective evaluation of the negative consequences or negative impact that may occur during 
travel and cognition of exceeding the threshold portion of the negative consequences or negative impact that may occur during travel.

2. There were two-dimensional impact factors (subjective) and the seven-dimensional impact factors (objective) of tourism risk perception. The former were the physical characteristics and psychological processes, and the latter include physical risk, economic risk, equipment risk, social risk, psychological risk, time risk and opportunity loss.

3. There were two types of risk perception assessment models, which were summarized as the multi-dimensional model and the two-factor model.

4. The survey (with interviews) and mathematical statistical analysis of tourism risk perception assessment;

5. The subjective and objective laws of travel risk perception's ability and level.

The development of the concept of tourism risk perception reflects the intersecting of economics, tourism, psychology and other disciplines. The theoretical and empirical studies of objective tourism risk (second level) and subjective tourism perception (first level) are more abundant, while the studies of the measure and define of tourism risk perception threshold (third level) are relatively less. The author's academic background relates to geography, environmental science, risk science and tourism. The paper intends to study tourism risk perception from the perspective of travel security management and tourism geographical systems and make the following ideas for reference:

1. The basis of tourism risk perception assessment is the science and rationality of the hypothesis. According to the empirical facts of tourism activities and the travel safety scientific theory, scholars can re-conceived and speculate the category, characteristics, spatial and temporal distribution of tourism risk factor (five- or seven-dimensional) and risk perception factors (subjective and objective). Only under the logical theoretical assumptions, the explanation of tourism risk perception is necessary and valuable;

2. The key of tourism risk perception assessment is the decision of the risk threshold that tourists can accept. Taking the physical characteristics, learning ability and practical experience of the respondents into account, scholars make sure the withstand value (tourist risk value) of tourism risk's consequences (such as personal injury, economic loss, psychological impact and decision-making behavior) and the probability of occurrence (percentage) through social survey methods;

3. The significance of tourism risk perception assessment is making tourism behavioral decision and destination security management. Acceptable risk has a positive feedback effect on tourists' decisions, and unacceptable risk (or an unacceptable dimension risk) has a guiding role for the risk of the tourist destination control. Targeted risk prevention and strategies are importantly significant for the decision motivate of tourists, sustainable use of tourism resources and cycle of development of the tourism industry.

Acknowledgments This work was financially supported by the National Natural Science Foundation of China (NSFC) (No. 41301580), the Philosophy and Social Sciences Research of Higher Learning Institutions of Shanxi (PSSR) (No. 2012216), the Qualified Personnel Foundation of TaiYuan University of Technology (No. TYUT-RC201110A) and Youth Foundation of Taiyuan University of Technology (No. 2015QN086). We gratefully acknowledge the thoughtful comments of the editor and reviewers. 


\section{References}

Ahmad FA, Mohd NII, Toh PS (2015) Sustainable Tourist Environment: Perception of international women travelers on safety and security in Kuala Lumpur. Procedia Soc Behav Sci 168:123-133

Ammann WJ (2006) Risk concept, integral risk management and risk governance. In: Ammann W, Dannenmann S, Vulliet L (eds) Risk 21-coping with risk due to natural hazards in the 21 st century. Taylor \& Francis Group, London, pp 3-24

An H, Fu R (2005) The subjective factors influence tourists risk perception and implications for tourism crisis management. Zhejiang Acad J 1:196-200 (in Chinese)

Atila Y, Fisun Y (2007) Shopping risk perceptions: effects on tourists' emotions, satisfaction and expressed royalty intensions. Tour Manag 28(3):703-713

Bauer RA (1960) Consumer behavior as risk taking. In: Hancock RS (ed) Dynamic marketing for a changing world, Proceedings of the 43rd. Conference of the American Marketing Association, pp 389-398

Beck U (1999) World risk society. Polity Press, Cambridge, p 184

Boksbergera PE, Biegerb T, Laesserb C (2007) Multi-dimensional analysis of perceived risk in commercial air travel. J Air Transp Manag 13:90-96

Brun W (1992) Cognitive components in risk perception: natural versus manmade risks. J Behav Decis Mak 5:117-132

Cao SX, Wang LJ (2001) Risk mitigation strategies and perception of tourism products. Tour Manag 1(1):1-26 (in Chinese)

Carol BB (2015) Tourism, crime and risk perception: an examination of broadcast media's framing of negative Aruban sentiment in the Natalee Holloway case and its impact on tourism demand. Tour Manag Perspect 16(10):266-277

Cater CI (2006) Playing with risk? Participant perceptions of risk and management implications in adventure tourism. Tour Manag 27:317-325

Chen YQ, Zhang H (2012a) Investigation of sports tourism visitors risk perception and coping behavior. J Hebei Inst Phys Educ 26(3):38-43 (in Chinese)

Chen YQ, Zhang H (2012b) Tourism risk cognitive theory and sports. J Suzhou Univ 27(1):87-91 (in Chinese)

Chen N, Qiao GH, Liu L (2009) Tourism association studies risk perception and outbound tourists travel preferences-tourists in Beijing. Geography 6:97-102 (in Chinese)

Chiao LY, Vikneswaran N (2014) Risk perception study in tourism: are we really measuring perceived risk? Procedia Soc Behav Sci 144:322-327

Cunningham SM (1967) The major dimensions of perceived risk. Harvard University Press, Boston, pp 82-108

Dirk G (2003) Crisis management in the tourism industry. Butterworth-Heinemann, Oxford, pp 41-57

Dolnicar S (2005) Understanding barriers to leisure travel: tourist fears as a marketing basis. J Vacat Mark 11(3):197-208

Eitzigera C, Wiedemannb P (2007) Risk perceptions in the alpine tourist destination Tyrol: an exploratory analysis of residents' views. Tour Manag 28:911-916

Fischer GW, Morgan MG, Fischhoff B et al (1991) What risks are people concerned about. Risk Anal 11(2):303-315

Fuchs G (2013) Low versus high sensation-seeking tourists: a study of backpackers' experience risk perception. Int J Tour Res 15:81-92

Fuchs G, Reichel A (2004) Cultural differences in tourist destination risk perception: an exploratory study. Tourism 52(1):21-37

Fuchs G, Reichel A (2006) Tourist destination risk perception: the case of Israel. J Hosp Leis Mark 14(2):81-106

Fuchs G, Reichel A (2011) An exploratory inquiry into destination risk perceptions and risk reduction strategies of first time vs. repeat visitors to a highly volatile destination. Tour Manag 32(2):266-276

$\mathrm{Hu}$ QZ (2011) Guest review of risk perception. Bus Cult 8:331-332 (in Chinese)

Huang J, Chuang S, Lin Y (2008) Folk religion and tourist intention avoiding tsunami-affected destinations. Ann Tour Res 35(4):1074-1078

Jones R, Boer R (2003) Assessing current climate risks adaptation policy framework: a guide for policies to facilitate adaptation to climate change [EB/OL], UNDP, in review http://www.undp.org/cc/apf-outline. htm

Kozak M, Crotts JC, Law R (2007) The impact of the perception of risk on international travelers. Int J Tour Res 9(4):233-242

Lepp A, Gibson H (2003) Tourist roles, perceived risk and international tourism. Ann Tour Res 30(3):606-624 
Li Y (2010) Tourists risk perception research after severe natural disasters-to Wenchuan earthquake restoration marketing, for example. J Theory Reform 2:85-88 (in Chinese)

Li M, Zhang J, Dong XW (2011) Cognitive research special tourist destination after natural Disasters-the "5.12" Wenchuan earthquake Jiuzhaigou example. Geogr Sci 66(12):1695-1706 (in Chinese)

Lin LZ, Hsu TH (2013) The analysis of risk perception with fuzzy means-end approach. Qual Quant 47(2):713-734

Liu Y (2009) Risk society theory and application value. Zhejiang Soc Sci 3:64-70 (in Chinese)

Liu J, Gao J (2008) Based tourism risk perception conceptual model-a case study of Shanghai residents. Tour Sci 22(5):37-43 (in Chinese)

Moreira P (2007) Stealth risks and catastrophic risks: on risk perception and crisis recovery strategies. J Travel Tour Mark 23(2):15-27

Moutinho L (1987) Consumer behavior in tourism. Eur J Mark 21(10):5-44

Myron FF, Heather G, Lori PG et al (2004) The effect of risk perceptions on intentions to travel in the Aftermath of September 11, 2001. J Travel Tour Mark 15(2-3):19-38

Oliver RL (1980) A cognitive model of the antecedents and consequences of satisfaction decisions. J Mark Res 17(11):460-469

People's Republic of China National Bureau of Statistics (2014) 2013 National economic and social development statistics bulletin People's Republic of China [EB/OL]. http://www.czs.gov.cn/fgw/ckwx/ content_423667.html (in Chinese)

Peter JP, Ryan MJ (1976) An investigation of perceived risk at the brand level. J Mark Res 13:184-188

Prashant B, Nicholas DF (2004) Problem solving in social interactions on the internet: rumor as social cognition. Soc Psychol Q 67(1):31

Quarantelli EI (1983) People's reactions to emergency warnings,transcript of the dam safety conference, August 23-24, 1983, University of Charleston, Charleston, West Virginia, Federal Emergency Management Agency, p 178

Reichel A, Fuchs G, Uriely N (2007) Perceived risk and the non-institutionalized tourist role: the case of Israeli student ex-backpackers. J Travel Res 46(3):217-226

Reisinger Y, Mavondo F (2006) Cultural differences in travel risk perception. J Travel Tour Mark 20(1):13-31

Roehl WS, Fesenmaier DR (1992) Risk perceptions and pleasure travel: an explanatory analysis. J Travel Res 30(4):17-26

Roselius E (1997) Consumer rankings of risk reduction methods. J Mark 35(1):56-61

Schiffman LG, Kanuk LL (2000) Consumer behavior. Prentice Hall, Upper Saddle River

Schneider LS, Dagerman KS, Insel P (2006) Atypical antipsychotic drugs, dementia, and risk of death-reply. J Am Med Assoc 295(5):496-497

Sitkin SB, Pablo AL (1992) Reconceptualizing the determinants of risk behavior. Acad Manag Rev 17:9-38

Slovic P (1987) Perception of risk. Science 236(4799):280-285

Sonmez SF, Graefe AR (1998a) Determining future travel behavior from past travel experience and perceptions of risk and safety. J Travel Res 37(2):171-177

Sonmez SF, Graefe AR (1998b) Influence of terrorism risk on foreign tourism decisions. Ann Tour Res 25(1):112-144

Suddle S (2009) The risk management of third parties during construction in multifunctional urban locations. Risk Anal 29(7):1024-1040

Teng WF (2009) Discussion travel risks and prevention. Market Mod 5:260-261 (in Chinese)

Tsaur SH, Tzeng GH, Wang GC (1997) Evaluating tourist risks from fuzzy perspectives. Ann Tour Res 24(4):796-812

United Nation (1989) International Decade for Natural Disaster Reduction, Resolution 44/236 adopted at the 44th session of the United Nations General Assembly [EB/OL]. http://www.un.org/ru/documents/ods. asp?m=A/RES/44/236

Wang FQ (2010) Risk society and the risk perception of the current Chinese population. J Shanghai Adm Inst 11(2):83-91 (in Chinese)

Whyte AVT, Burton I (1982) Perception of risks in Canada. In: Burton I, Fowle CD, McCullough RS (eds) Living with risk: environmental risk management in Canada. Environmental Monograph No. 3, Institute for Environmental Studies, University of Toronto, Canada, pp 39-69

Wong J, Yeh C (2009) Tourist hesitation in destination decision making. Ann Tour Res 6(1):6-23

Wu BH, Wang X, Li MM (2001) Chinese college students perceive the evaluation of tourism security research. J Guilin Inst Tour 12(3):62-68 (in Chinese)

Xie F, Xu A (1996) Public perception of bias in risk. Psychology 4(2):23-26 (in Chinese)

Yvette R, Felix M (2005) Travel anxiety and intentions to travel internationally: implications of travel risk perception. J Travel Res 43(3):212-225 
Zhang JK (2009) Tourism risk perception research of domestic tourists in Tibet. J Sichuan Norm Univ (Soc Sci) 36(6):111-118 (in Chinese)

Zhang JK (2012a) Optimization and empirical model of tourism risk perception. J Tibet Natl Inst (Philos Soc Sci Ed) 33(2):45-48 (in Chinese)

Zhang JK (2012b) Tourism risk perception and measurement-based on the survey of college students traveling to Tibet. Ind Econ Rev 7:106-114 (in Chinese)

Zhang SY, Yi WC, Wang EP (2004) Consumer psychology of risk perception. Adv Psychol Sci 12(2):256-263 (in Chinese)

Zhang H, Xu FM, Li B (2013) Based on risk perception of climate change. Adv Psychol Sci 21(9):1677-1685 (in Chinese)

Zheng XM (2009) Travel safety introduction. China Tourism Press, Beijing, pp 60-76 (in Chinese)

Zhu XY (2008) Women travel safety perception evaluation based on the theory of tolerance zones. Zhejiang Gongshang Univ 7-18 (in Chinese) 